Драгобецький В. В. Кузсв I. O. Молоштан Д. В. Наумова О. 0. Долударєв В. М.

\title{
ЗАКОНОМІРНОСТІ ПРОЦЕСУ ЗГИНАННЯ БІМЕТАЛЕВИХ ДУГ ПАСАЖИРСЬКИХ ВАГОНІВ
}

Шаруваті метали знайшли широке застосування в багатьох галузях промисловості. Їх застосування обумовлено можливістю створення виробів з комплексом фізико-механічних властивостей недосяжних в монометалу, при економії чорних і кольорових металів. I якщо питання застосування дорогих сплавів із застосуванням шаруватих металевих композицій в різних конструкціях досить глибоко розкриті й обгрунтовані $[1,2,3]$, то технологічні аспекти та можливості їх використання в повній мірі ще не розкриті.

Аналіз останніх досліджень і літератури. Використання принципу шаруватості для вирішення комплексу технологічних завдань в процесах листового штампування розглянуто в роботах $[3,4]$. Однак далеко не всі аспекти застосування біметалів для вирішення завдань економії дорогих сплавів в процесах металообробки висвітлені в науково-технічній літературі і теоретично необгрунтовані і не описані.

У виробництві засобів наземного, водного і повітряного транспорту знаходять застосування силові елементи, одержувані з профілів згинанням з розтягуванням (дуги пасажирських вагонів, шпангоути, лонжерони, балки і т. д.). Для їх виготовлення все ширше використовуються нержавіючі стали, титанові і високоміцні алюмінієві сплави. При згинанні і при згинанні з розтягуванням неминучі втрати металу через затиску кінцевих зон в затискних патронах та їх закруткою [1].

Уникнути втрат можна при використанні зварної заготовки, що складається з дорогого матеріалу - центральна частина і периферійних ділянок - 3 дешевого. Наприклад, дуги пасажирських вагонів, що застосовуються в широкому асортименті на ПАТ «Крюківський вагонобудівний завод» доцільно і економічно обгрунтовано фахівцями підприємства, виготовляти з зварної заготовки нержавіюча сталь (Х18Н10Т) + вуглецева сталь (08кп).

Процес згинання з розтягуванням бінарної (складеної) заготовки має значні відмінності від процесу деформації монолітної заготовки. Ці відмінності в основному пов'язані з відсутністю ізотропності середовища і розривної неоднорідністю іiї властивостей. Тому виникла необхідність в аналізі розтягування і вигину бінарної системи і уточнення моделі процесу спільного пластичного деформування різних металів. При попередньому розтягуванні профільних заготовок з різнорідних металів на згинально-розтягувальних машинах зовнішнє тертя відсутнє.

Фізична модель процесу одноосного розтягу бінарної системи відповідає моделі розтягування шаруватого тіла при вільних умовах на контурі. Однак, при подальшій згинанні і калібрувальному розтягуванні зовнішнє тертя на одному 3 контурів грає істотну роль на процес деформування бінарної системи.

Метою дослідження $є$ розробка моделі та визначення технологічних параметрів деформування профільної біметалевої заготовки з повздовжнім розташуванням шарів різних металів при зовнішньому терті на одному з контурів.

При попередньому розтягуванні заготовки з різнорідних матеріалів, зону зварного шва не враховуємо, зовнішнє тертя і міжшарове тертя відсутнє. Основний матеріал (центральна частина заготовки), як правило, менш пластичний (Н), а периферійний більш пластичний (S). При попередньому розтягуванні профільної заготовки з монолітного матеріалу зусилля попереднього розтягування $\mathrm{P}_{\mathrm{st}}$ визначалося по залежності $\mathrm{P}_{\mathrm{st}}=\sigma_{\mathrm{s}} \mathrm{F}$, де $\sigma_{\mathrm{s}}-$ поточ- 
ний межа плинності матеріалу заготовки; F - площа поперечного перерізу заготовки. При заготовці з різнорідних матеріалів в першу чергу почне деформуватися матеріал $\mathrm{S}$. Його деформація буде тривати до тих пір поки його поточний межа плинності при розтягуванні не стане порівняно 3 початковим межі текучості при розтягуванні матеріалу F. Якщо матеріал $\mathrm{S}$ не зміцнюється, то спільна пластична деформація різних металів неможлива. Буде тільки деформуватися матеріал $\mathrm{S}$ до його повного розриву. Перші спроби виготовлення дуг пасажирських вагонів були вдалі при порушенні режимів зварювання (перегрів зони зварного шва) зона зварного шва несхильна до деформаційного зміцнення руйнувалося (рис. 1).

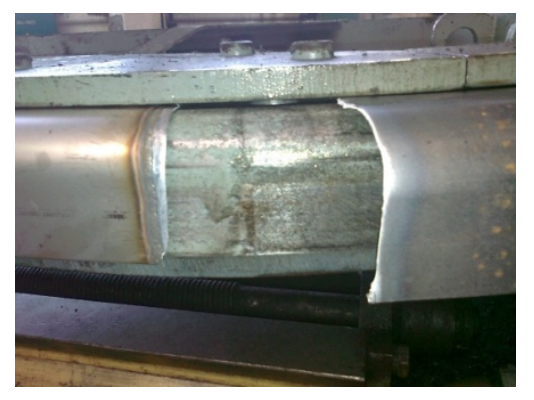

Рис. 1. Розрив зварного шва при згинанні з розтягуванням дуг пасажирських вагонів з різнорідних металів

Діаграма справжніх напруг для стали 08кп апроксимується в повній третього ступеня або степенної функцією [5]:

$$
\sigma_{s}=240+1279 \varepsilon-1599 \varepsilon^{2}+914 \varepsilon^{3}=230+548 \varepsilon^{0,6},
$$

де $\sigma_{\mathrm{s}}$ - границя плинності матеріалу; $\varepsilon$ - інтенсивність деформацій.

Для нержавіючої корозійностійкої сталі ця діаграма апроксимується залежністю

$$
\sigma_{i}=1490\left(0,016+\varepsilon_{i}\right)^{0,5}=470+2691,6 \varepsilon-5508,7 \varepsilon^{2}+4185,2 \varepsilon^{3} .
$$

Однак, криві зміцнення не мають спільних точок перетину і спільна пластична деформація виявилася неможливою. Тому, сталь 08кп була замінена сталлю 15ЮА.

Зусилля попереднього розтягування заготовки з різнорідних матеріалів доцільно визначати за залежністю

$$
P_{s t}=\sigma_{s t} F
$$

де $\sigma_{\mathrm{st}}$ - ордината перетину кривих зміцнення матеріалів заготовки.

При цьому $\sigma_{\mathrm{st}}>\sigma_{\mathrm{com}}$, де $\sigma_{\mathrm{com}}$ напруга стиснення при вигині заготовки.

Крім того, деформації $\varepsilon_{\text {st }}$, які відповідають $\sigma_{\text {st }}$ повинні задовольняти умові $\varepsilon_{\mathrm{st}}<\varepsilon_{\mathrm{ss}}+\varepsilon_{\mathrm{b}}$, де $\varepsilon_{\mathrm{ss}}-$ гранична деформація менш міцного матеріалу; $\varepsilon_{\mathrm{b}}$ - максимальна деформація заготовки при вигині.

При розтягуванні на заключній стадії процесу розтягування + згинання + розтягування вигнута профільна заготовка обтягується по пуансону, приймаючи при цьому задану форму та розміри. Сили тертя, що діють між заготовкою і пуансоном, зменшують розтягуючі зусилля в міру віддалення від крайніх точок дотику заготовки з пуансоном. При цьому менш навантаженими виявляється перетин, розташованим в середині осередку деформацій. Найменш навантаженим є перетин профілю розташованого в середині осередку деформації. Тому, при калібрувальній операції розтягування після згинання, обмежуючим фактором є руйнування заготовок на вільних, найбільш навантажених ділянках. Тому, економічні переваги, пов'язані з економією металу, доповнені технічними. Останні пов'язані з доцільністю вико- 
ристання пластичних металів в периферійних ділянках. При цьому зварний шов розташовуваний в зоні контакту з пуансоном. Загальне зусилля розтягування можна представити в наступному вигляді:

$$
P=P_{\alpha}+P_{f}+P_{b}
$$

де $\mathrm{P}_{\alpha}$ - зусилля деформування заготовки в даному перетині;

$\mathrm{P}_{\mathrm{f}}-$ сила зовнішнього тертя;

$\mathrm{P}_{\mathrm{b}}$ - зусилля згинання.

У першому наближенні вплив згинальних напружень і деформацій можна не враховувати. Це припущення досить обгрунтовано, так як радіус кривизни деталі істотно більше іiі товщини.

Вигин заготовки після попереднього розтягування до деформацій, відповідних перетинанню кривих зміцнення металів складовою заготовки, відбувається в умовах спільної пластичної деформації різнорідних металів. 3 огляду на те, що деформації заготовки незначні, то зусилля згинання визначається по відомим залежностям [5].

При спільній пластичній деформації бінарної заготовки (рис. 3) компоненті останньої гальмуються силами зовнішнього тертя в зоні контакту з пуансоном.

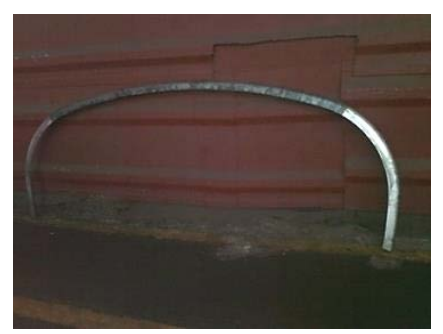

Рис. 2. Дуга пасажирського вагона з різнорідних металів після згинання з розтягуванням

Для аналізу даного процесу формозміни (фланцевої частини заготовки, згинальні) необхідно вказати закон, за яким повинні змінюватися напруги зовнішнього тертя на контактних поверхнях заготовки. В теорії обробки металів тиском застосовують залежності для визначення величини напруги контактного тертя у яких в якості аргументу міститься будь-який фізичний фактор (нормальний тиск, межа плинності, в'язкість мастила та ін.).

При пластичній формозміні металів зовнішне тертя грає істотну роль на ефективність протікання процесів деформування в широких межах. При визначенні напружень контактного тертя та коефіцієнта тертя необхідно враховувати специфіку контактної взаємодії й поняття коефіцієнта тертя при обробці металів тиском. Особливостями контактного тертя при обробці металів тиском є високі контактні напруги при пластичній деформації поверхневого шару, протікання процесів зміцнення, роззміцнення й структурних перетворень [1]. Крім того поняття «коефіцієнта тертя» при обробці тиском може мати неоднозначне тлумачення, яке пов'язане зі специфічними контактними умовами в зоні контактної взаємодії заготовки з інструментом [2]. При ковзанні заготовки по поверхні інструменту відповідає поняттю коефіцієнта тертя в механічному сенсі, тобто відношення питомої сили тертя до нормального тиску. Однак, якщо в осередку деформації в зоні контакту існує зона прилипання, то сила тертя не залежить від фізичних умов на поверхні, а залежить від внутрішньої напруги металі, що деформується, тобто від схеми напружено-деформованого стану елемента заготовки. При обробці тиском, якщо на контактній поверхні є зона прилипання, то величина коефіцієнта тертя є середнім умовним коефіцієнтом тертя, що залежить від протяжності зони прилипання [2]. Тому поділяють коефіцієнт тертя умовний і фізичний і класифікують за стадіями процесу [2]. Стосовно до процесів витяжки гнуття, формування, роздачі в залежності від стадії процесу це може бути: коефіцієнт тертя в момент початку переміщення заготовки, в умовах пружного та пластичного деформування і при сталому процесі деформування. 
Теоретично врахувати напруги контактного тертя на фланцевій частині заготовки надзвичайно важко. Використання для визначення контактних дотичних напружень закону Амонтона - Кулона, призводить до значних відмінностей (в 22,6 рази) розрахункових результатів з експериментальними. Для аналізу процесів обробки металів тиском, в яких переважає розтягуючі напруги, в тому числі при складній витяжці слід прийняти формулу Зібеля. Однак, в довідковій літературі коефіцієнти тертя, що входять в формулу Зібеля, не наводяться.

Але незважаючи на це найбільш широко застосовуваним є закон тертя АмонтонаКулона, який встановлює пропорційну залежність між силою тертя і нормальної стискаючою силою. Закон Амонтона-Кулона виконується найбільш точно при холодній пластичній деформації з застосуванням технологічних мастил. У жорстких умовах тертя при відношенні сили тиску до межі плинності вище 2-3, при відсутності змащення застосовують закон Зібеля [3]. Напруги тертя визначимо по залежності:

$$
\sigma_{\text {тр }}=\frac{\mu^{F} q l^{F} B}{F_{p}}+\frac{\mu^{S} q l^{S} B}{F_{p}},
$$

де $\mu^{\mathrm{F}}, \mu^{\mathrm{S}}$ - коефіцієнти тертя металів $\mathrm{F}$ i S по пуансону;

В - ширина полиці;

$1^{\mathrm{F}}, 1^{\mathrm{S}}$ - довжини ділянок контакту пуансона з матеріалом $\mathrm{F}$ i S ,

$\mathrm{F}_{\mathrm{p}}$ - площа поперечного перерізу профілю.

Напруження, що діють в різних перетинах заготовки на заключній стадії розтягування:

I зона вільної ділянки, розташована між поверхнею пуансона i захисного патрона. На цій ділянці сили зовнішнього тертя відсутні, а деформації не повинні перевищувати граничної деформації металу $\sigma_{\mathrm{s}}$. Граничне зусилля розтягування складе:

$$
P_{s t}=F\left(\sigma_{o s}+A_{s} \varepsilon_{i 1}^{n s}\right)=F\left(\sigma_{o s}+A_{s} \varepsilon_{i 2}^{n s}\right)=F\left(\sigma_{o t}+A_{f} \varepsilon_{i F}^{n F}+\sigma_{m p}\right),
$$

де $\mathrm{A}_{\mathrm{s}}, \mathrm{A}_{\mathrm{F}}, \mathrm{n}_{\mathrm{s}}, \mathrm{n}_{\mathrm{F}}$ - модулі зміцнення і показники системи зміцнення матеріалів $\mathrm{S}$ i F; $\sigma_{\mathrm{os}}$ i $\sigma_{\mathrm{oF}}$ - деформації плинності матеріалів $\mathrm{S}$ i F;

II зона контакту матеріалу S з поверхнею пуансона;

III зона контакту матеріалу F 3 поверхнею пуансона.

Результати досліджень.

Розрахунок параметрів процесу згинання проводиться в такій послідовності:

1. Накладення кривих зміцнення матеріалів заготовки і визначення точки їх перетину.

2. Визначення зусилля попереднього розтягування заготовки по залежностям (5) і (6) і деформацій.

3. Визначення номінального зовнішнього моменту згинання заготовки й згинальних деформацій.

4. Визначення каліброваного розтягування і граничних деформацій. Результати розрахунків наведені в табл. 1.

Результати розрахунків каліброваного розтягування і граничних деформацій

\begin{tabular}{|c|c|c|c|c|c|}
\hline $\begin{array}{c}\text { № } \\
\text { П/П }\end{array}$ & $\begin{array}{c}\text { Марка сталі } \\
\text { № деталі }\end{array}$ & Вид профілю & $\sigma_{\mathrm{p}}, \mathrm{M \Pi а}$ & $\mathrm{F}, \mathrm{m}^{2}$ & $\mathrm{P}_{\mathrm{st}}, \mathrm{\kappa H}$ \\
\hline 1 & $\begin{array}{c}\text { 08Х18Н10Т + 15ЮА } \\
77067.235 .001\end{array}$ & $\begin{array}{c}\text { Зетовий } \\
\text { нормалізація }\end{array}$ & 509 & $3,75 \cdot 10^{-4}$ & 190,9 \\
\hline
\end{tabular}




\section{ВИСНОВКИ}

Встановлено доцільність застосування профільних заготовок з різнорідних матеріалів для виготовлення методом згинання з розтягуванням елементів каркасу транспортних засобів, наприклад дуг пасажирських вагонів.

Зусилля попереднього розтягування розраховується, як добуток поточної площі профільної заготовки на напругу поточного межі текучості, який відповідає точці перетину кривих зміцнення матеріалів заготовки. Зусилля згинання визначається як для монолітної заготовки при рівних поточних межах плинності ії матеріалів. Калібрувальне розтягнення відповідає граничним деформаціям більш пластичного матеріалу.

\section{СПИСОК ВИКОРИСТАНОЇ ЛІТЕРАТУРИ}

1. Гайкова Т.В., Пузырь Р.Г., Наумова Е.А. Результаты экспериментальных исследований по деформированию слоистых заготовок. Вісник НТУ «ХПI». Харків. 2013. 42 (2015). С. 37-42.

2. Воронцов А.Л. К вопросу о контактном трении, кривых упрочнения и эффекте Баушингера. Кузнечно-итамповочное производство. Обработка материалов давлением. 2011. 3. С. 39-47.

3. Пузырь Р.Г. Применение многослойных металлов и особенности их пластической деформации. Bicник НТУ «ХПI». Харків. 2012. 66 (972). С. 31-34.

4. Битков В.В. Оценка неоднородности деформации при пластической обработке осесимметричных биметаллических изделий. Кузнечно-итамповочное производство. Обработка материалов давлением. 2011.5. C. 3-12.

5. Драгобецький В.В., Мороз М.М., Мосьпан Д.В., Пузир Р.Г. Розрахунок технологічних параметрів отримання деталей з елементом жорсткості послідовної гнучкою. Обработка материалов давлением. Краматорск: ДГМА. 2010.4 (25). С. 133-137.

\section{REFERENCES}

1. Gaikova T. V., Puzyr R. G., Naumova E. A. Results of experimental studies on the deformation of layered workpieces. Bulletin of NTU "KhPI". 2013. 42 (2015), pp. 37-42. (in Russian).

2. Vorontsov A.L. On contact friction, hardening curves, and the Bauschinger effect. Forging and Stamping Production. Materials Working by Pressure. 2011. 3, pp. 39-47. (in Russian).

3. Puzyr R. G. Use of multilayer metals and features of their plastic deformation. Bulletin of NTU "KhPI". 2012. 66 (972), pp. 31-34. (in Russian).

4. Bytkov V.V. Assessment of deformation inhomogeneity during plastic processing of axisymmetric bimetallic products. Forging and Stamping production. Materials Working by Pressure. 2011. 5, pp. 3-12. (in Russian).

5. Dragobetsky V.V., Moroz M.M., Mospan D.V., Puzyr R.G. Calculation of technological parameters for obtaining parts with a stiffening element consistent flexible. Materials Working by Pressure. Kramatorsk: DSEA. 2010. 4 (25), pp. 133-137. (in Ukrainian).

Драгобецький В. В. - д-р техн. наук, проф. КрНУ ім. Остроградського;

Кузєв I. О. $\quad$ - асистент КрНУ ім. Остроградського;

Молоштан Д. В. - старший викладач КрНУ ім. Остроградського;

Наумова О. О. - - інженер КрНУ ім. Остроградського;

Долударєв В. М. - канд техн. наук, доц. КрНУ ім. Остроградського.

КрНУ ім. М. Остроградського - Кременчуцький національний університет імені Михайла Остроградського

E-mail: vldrag@kdu.edu.ua 